\title{
Stereological evaluation of Sertoli cell ontogeny during fetal and neonatal life in two diverse breeds of swine
}

\author{
S A McCoard, T H Wise, D D Lunstra and J J Ford \\ United States Department of Agriculture, Agricultural Research Service, US Meat Animal Research Center, Clay Center, Nebraska 68933, USA \\ (Requests for offprints should be addressed to S A McCoard, Nutrition and Behavior Group, AgResearch Limited, Grasslands Research Centre, \\ Private Bag 11008, Palmerston North, New Zealand; Email: sue.mccoard@agresearch.co.nz) \\ (S A McCoard is now at Nutrition and Behavior Group, AgResearch Limited, Grasslands Research Centre, Private Bag 11008, Palmerston North, \\ New Zealand)
}

\begin{abstract}
Chinese Meishan (MS) boars have smaller testes due to fewer Sertoli cells compared with White Composite (WC) boars. The objective was to describe Sertoli cell development relative to circulating FSH concentrations in fetal and neonatal MS and WC boars. Testes and blood samples were collected on days $60,75,90$ and 105 postcoitum (dpc) and 1, 7, 14 and 25 postpartum (dpp). One testis was immunostained for GATA4 or Ki67 antigen to evaluate total and proliferating Sertoli cell numbers respectively. Testicular size was greater $(P<0 \cdot 01)$ in WC than MS boars at all ages, associated with a greater mass of interstitial tissue. Tubular mass $(P<0 \cdot 01)$ was greater in prenatal WC boars, but postnatally increased more rapidly $(P<0 \cdot 001)$ in MS boars, exceeding WC boars by $25 \mathrm{dpp}$. Sertoli cell numbers increased with age, was greater $(P<0.001)$ in WC than MS boars during prenatal development but increased rapidly $(P<0 \cdot 01)$ by $1 \mathrm{dpp}$ in MS and thereafter was similar in both breeds. The proportion of Ki67-
\end{abstract}

positive Sertoli cells was maximal at $90 \mathrm{dpc}$, declining thereafter, did not differ between breeds through $7 \mathrm{dpp}$, but was greater $(P<0.05)$ in WC than MS boars at 14 and 25 dpp. Plasma FSH concentrations were greater $(P<0.05)$ in WC than MS boars at $75 \mathrm{dpc}$. FSH concentrations were elevated at $105 \mathrm{dpc}(\mathrm{MS})$ and $1 \mathrm{dpp}$ (WC) but declined thereafter with advancing postnatal age in both breeds. This study illustrates that late gestation represents the period of maximal Sertoli cell proliferation. Despite asynchronous Sertoli cell population growth between breeds during early postnatal life, differential mature Sertoli cell numbers and testicular size are probably due to differences in duration of the proliferative period after $25 \mathrm{dpp}$, potentially regulated by Sertoli cell maturation and blood-testis barrier formation. These events were not associated with fetal or early postnatal changes in FSH secretion.

Journal of Endocrinology (2003) 178, 395-403

\section{Introduction}

Sertoli cell numbers determine adult testicular size (Orth 1984, Russell et al. 1990, Chubb 1992), thereby establishing an upper limit for total daily sperm production. Thus boars with large testes provide an opportunity to decrease production costs for artificial insemination while simultaneously allowing use of genetically superior sires. Identification of factors that control adult Sertoli cell population size is necessary to develop methodologies that either predict adult testicular size at a young age, such as by marker-assisted selection, or enhance adult testicular size and thus sperm production.

Male sexual differentiation in pigs is initiated at 26 days postcoitum (dpc) (Pelliniemi 1975, McCoard et al. 2001b) and is characterized by differentiation of Sertoli cells from precursor somatic cells and formation of testicular cords (Tung et al. 1984, Tung \& Fritz 1987). Leydig cells in the interstitial compartment differentiate shortly thereafter, initiating androgen-stimulated development of the male phenotype. Sertoli cell numbers increase during fetal and neonatal life, reaching maximum numbers prior to terminal differentiation of the Sertoli cell population. Sertoli cell maturation is characterized by acquisition of a characteristic shape and nuclear features (Fawcett 1975), bloodtestis barrier formation (Tindall et al. 1975) and cessation of mitotic activity (Gondos \& Berndtson 1993). Coincident with Sertoli cell maturation, lumen formation occurs within seminiferous tubules and germ cells proliferate rapidly followed by onset of spermatogenesis.

Several indirect studies of Sertoli cell development in pigs indicate that the early postnatal period corresponds to the most rapid rates of Sertoli cell proliferation (Tran et al. 1981, Putra \& Blackshaw 1985, Kosco et al. 1987, Swanlund et al. 1995). During the first month of life there is a 6-fold increase in the number of Sertoli cells (Franca et al. 2000) and between 1 and 14 days of age approximately $15-30 \%$ of the total Sertoli cell population are 
undergoing proliferation (McCoard et al. 2001a). Increased follicle-stimulating hormone (FSH) secretion (Lunstra et al. 1997) during this time has been assumed to be the stimulus for this proliferation as occurs in rats (Meachem et al. 1996, Baker \& O'Shaughnessy 2001). In the present study, two genetically diverse breeds of swine, Meishan (MS) and White Composite (WC) were compared because they differ in adult testicular size, Sertoli cell number and sperm production (Okwun et al. 1996, Lunstra et al. 1997). The objective was to describe patterns of Sertoli cell development in purebred MS and straightbred WC boars during late fetal and early neonatal life and to relate these developmental patterns to circulating FSH concentrations.

\section{Materials and Methods}

\section{Sample collection and histological methods}

Fetal and early neonatal boars were obtained from either purebred MS or WC (Yorkshire $\times$ Landrace) sows (Sus scrofa). Estrus was checked once daily, and sows were bred on the first and second day of detected estrus. Day 0 (for fetal samples) corresponds to the first day of mating, and 1 day postpartum (dpp) corresponds to $12-24 \mathrm{~h}$ following parturition. Pregnant sows $(60,75,90$ and $105 \mathrm{dpc})$ were slaughtered by electrical stunning followed by exsanguination. Fetal boars were produced by nine WC and eight MS sires. Fetal blood samples were obtained from the umbilical artery; body weight was recorded, and testes were collected from fetal boars with at least three to five litters represented per age group per breed $(n=6-10$ boars per breed per age). Neonatal blood samples were obtained by vena caval puncture, prior to castration on $1 \mathrm{dpp}$, from ten MS boars, produced by six sires, and ten WC boars, produced by seven sires, each from different litters. Littermates to each of these boars were castrated on 7, 14 and $25 \mathrm{dpp}$. These age groups represent early gonadotropin secretion in the porcine fetus (Liwska 1975, Goxe et al. 1993) and the neonatal peak in gonadotropin secretion (Lunstra et al. 1997). Procedures for handling all animals in this study complied with those specified in the Guide for the Care and Use of Agricultural Animals in Agricultural Research and Teaching (FASS 1999).

The left testis from each boar was trimmed of epididymides and excess connective tissue and weighed. Fetal testes were processed intact and postnatal testes were cut into two pieces longitudinally. Tissues were fixed overnight in two changes of $4 \%$ paraformaldehyde in PBS $(\mathrm{pH}$ $7 \cdot 6)$ at $4{ }^{\circ} \mathrm{C}$ with gentle agitation. Each sample was washed in PBS $(1 \times 1 \mathrm{~h})$, dehydrated through graded percentages of ethanol $(50,70,80,90,100 \%, 2 \times 1 \mathrm{~h}$ each), cleared in xylene (Sigma) $(2 \times 1 \mathrm{~h}$; $)$, infiltrated with paraffin wax $\left(60{ }^{\circ} \mathrm{C}, 4 \times 1 \mathrm{~h}\right)$, and embedded in paraffin wax. Four longitudinal serial sections $(5 \mu \mathrm{m})$ were made from the middle of the left testis of each animal. Approximately the same region of each testis was used. Sections were dried overnight onto glass slides at $37^{\circ} \mathrm{C}$ and stored at room temperature until staining. Sections were stained immunohistochemically for GATA4, a marker for Sertoli cells, and Ki67 antigen as described previously (McCoard et al. 2001a).

\section{Stereological evaluation of testicular composition}

Sections stained for GATA4 or Ki67 antigens were examined under brightfield microscopy. Briefly, Sertoli cell and germ cell morphological characteristics including total number, nuclear volume and proportion undergoing proliferation (Ki67-positive) were determined from four randomly selected regions (quadrants) of each longitudinal section. Approximately $5 \times 10^{6} \mu^{2}$ were evaluated per testis $\left(1.2 \times 10^{6} \mu \mathrm{m}^{2}\right.$ per quadrant). At least $250 \mathrm{semin}-$ iferous tubules were measured at $\times 200$ per testis. For determination of nuclear size, four round tubules were selected per quadrant and Sertoli cell number, germ cell number and nuclear volumes within each tubule were determined at a magnification of $\times 1000$. At least 600 Sertoli and 40 germ cell nuclei were measured per testis in each age group. Detailed stereological methods are described elsewhere (McCoard et al. 2001b). All measurements were made using computerized morphometic planimetry (Bioquant Nova 2000 Advanced Image Analysis; R\&M Biometrics, Nashville, TN, USA); calculations for testicular parameters were conducted as described previously (McCoard et al. 2001a).

\section{FSH assay}

Plasma concentrations of FSH were determined by RIA using anti-porcine FSH (AFP2062096Rb) and porcine FSH (AFP10640B) (from Dr A F Parlow, National Hormone and Peptide Program, National Institute of Diabetes, Digestive and Kidney Diseases, Bethesda, MD, USA) for iodination and for the reference preparation. All samples were included within a single assay. Data from fetuses collected at $60 \mathrm{dpc}$ were not included in the statistical evaluation because FSH concentrations were below the limits of sensitivity, $0 \cdot 2 \mathrm{ng} / \mathrm{ml}$, for $44 \%$ of the WC and $30 \%$ of the MS fetuses. The intra-assay coefficients of variation for three serum pools that assayed $1 \cdot 2$, $2 \cdot 1$ and $3.6 \mathrm{ng} / \mathrm{ml}$ were $5 \cdot 2,9 \cdot 0$ and $4 \cdot 9 \%$ respectively.

\section{Statistical analysis}

Differences between breeds in all components estimated were tested using mixed model procedures; the repeated measure procedure was used with all morphological data (SAS 1999). For fetal samples, the model included fixed effects of breed, age and breed $\times$ age interactions and random effects of litter nested within breed. For postnatal samples, the model included fixed effects of breed, age and breed $\times$ age interaction and random effects of litter. 

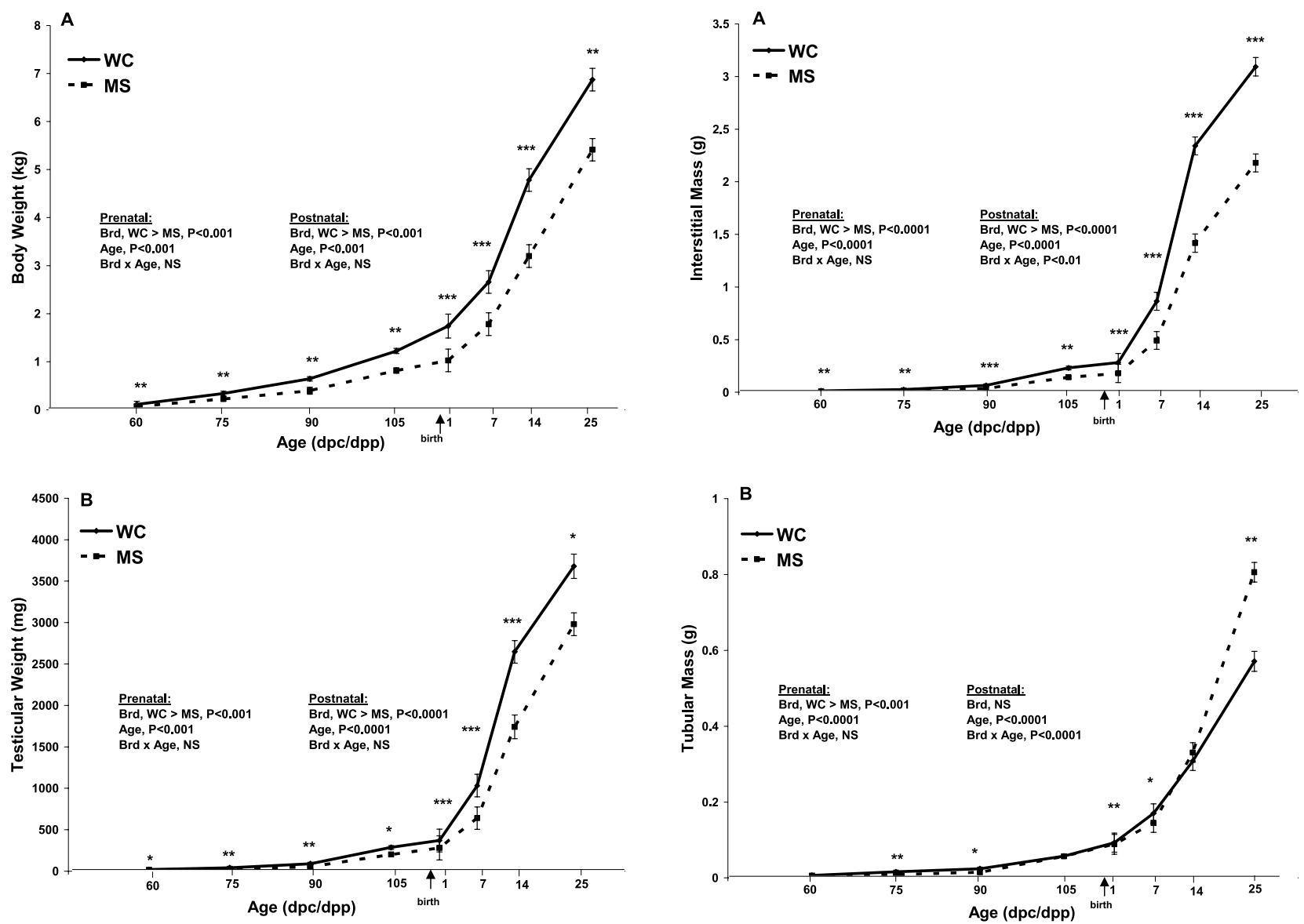

Figure 1 (A) Body weight and (B) testis weight of Meishan (MS) and White Composite (WC) boars during fetal and neonatal life. Data are LSMs \pm S.E. ${ }^{*} P<0 \cdot 05 ;{ }^{*} P<0 \cdot 01 ;{ }^{* * *} P<0 \cdot 001 ;$ dpc, days postcoitum; dpp, days postpartum; Brd, breed; NS, not significant.

Quadrant was the repeated measure. Use of a covariate was used to adjust for fetal weight within breed and age or for birth weight within breed in the statistical models that assessed testicular weight, mass of tubules and interstitium, and number of Sertoli and germ cells. Paired comparisons were made using the Tukey-Kramer procedure. Data were transformed to logarithms to adjust for heterogeneity of variance when required but are presented as least square means (LSMs) with standard errors.

\section{Results}

Body weight increased with advancing age in both breeds $(P<0.001)$; WC boars were heavier than MS boars (Fig. 1A). Likewise, testicular weight increased with age $(P<0 \cdot 001)$, and WC boars had larger testes than MS boars (Fig. 1B). No differences were observed in any testicular morphological parameters between different quadrants of the testis sampled. The mass of interstitial tissue was

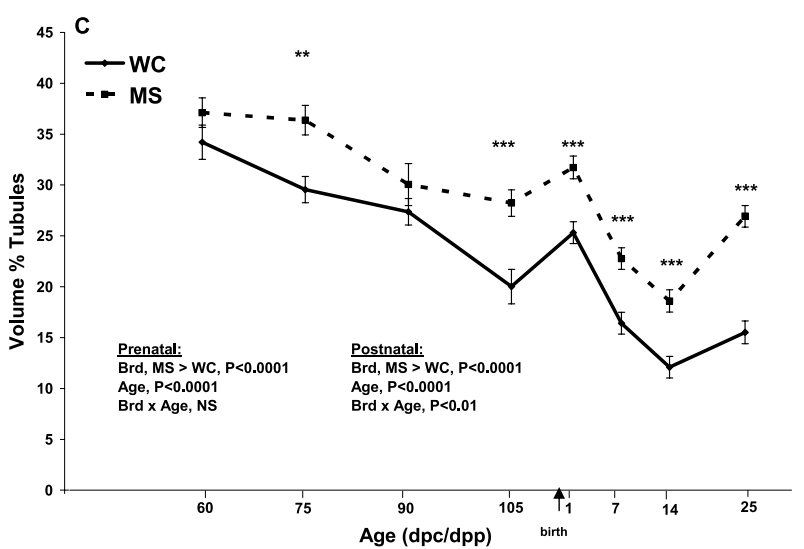

Figure 2 (A) Interstitial mass, (B) seminiferous tubule mass and (C) proportion of the testis occupied by seminiferous tubules of the left testis in Meishan (MS) and White Composite (WC) boars during fetal and neonatal life. Data are LSMs \pm S.E. ${ }^{*} P<0 \cdot 05$; ${ }^{* *} P<0 \cdot 01 ;{ }^{* * *} P<0 \cdot 001 ;$ dpc, days postcoitum; dpp, days postpartum; Brd, breed; NS, not significant.

greater in WC boars at all ages (Fig. 2A) and increased more rapidly during early postnatal development in WC than in MS boars. Tubular mass was greater in WC boars 
Table 1 Characteristics of testicular structures (LSM \pm S.E. during fetal and early postnatal life in Meishan (MS) and White Composite (WC) boars

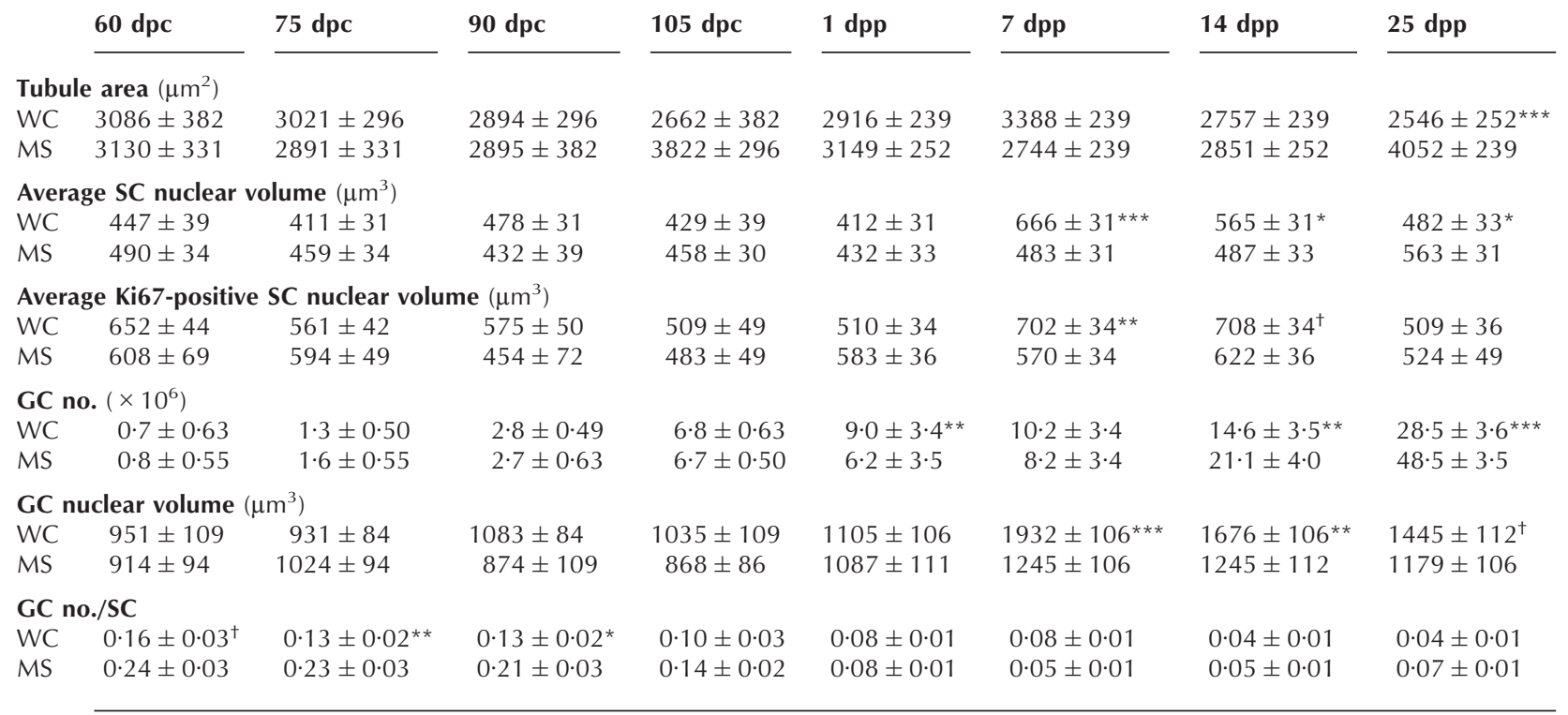

${ }^{\dagger} P<0 \cdot 10 ;{ }^{*} P<0 \cdot 05 ;{ }^{* *} P<0 \cdot 01 ;{ }^{* *} P<0 \cdot 001 ; \mathrm{dpc}$, days postcoitum; dpp, days postpartum; SC, Sertoli cell; GC, germ cell.

during prenatal development, but tubular mass increased more rapidly in postnatal MS boars such that MS boars had a greater tubular mass than WC boars at $25 \mathrm{dpp}$ (Fig. 2B). Similarly, seminiferous tubule size remained relatively constant until $25 \mathrm{dpp}$, when MS boars had considerably larger tubules compared with WC boars (Table 1; Fig. 3A and $\mathrm{B})$. The proportion of the testis occupied by tubules declined with advancing age $(P<0.001)$ until $14 \mathrm{dpp}$, followed by a small increase in both breeds by $25 \mathrm{dpp}$ (Fig. 2C). Volume \% of tubules was consistently higher in MS than WC testes (Fig. 2C). Conversely, the proportion of the testis composed of interstitial tissue increased with age $(P<0.001)$ and was consistently greater in WC than MS testes (data not presented). General morphology of seminiferous tubules was similar between breeds. However, extremely large tubules with considerably more Sertoli cells and germ cells, reminiscent of egg cell nests in the porcine fetal ovary, were often observed in testes from MS boars (Fig. 3C).

The total number of Sertoli cells per testis increased with age $(P<0 \cdot 001)$, and was greater prenatally in WC than in MS boars (Fig. 4A). Postnatally, the number of Sertoli cells increased rapidly in MS to be greater $(P<0 \cdot 01)$ on $1 \mathrm{dpp}$ than observed in WC boars. The average nuclear volume of Sertoli cells remained constant during fetal life but increased during the postnatal period $(P<0 \cdot 001)$; this increase was asynchronous between the two breeds $(P<0 \cdot 001$; Table 1$)$. WC boars had larger Sertoli cell nuclei compared with MS boars at 7 and 14 dpp but the reverse was observed at $25 \mathrm{dpp}$ (Table 1). The average nuclear volume of Ki67-positive Sertoli cells tended to be larger than the average nuclear volume of the total Sertoli cell population (Table 1). WC boars had larger Ki67-positive Sertoli cell nuclei at $7 \mathrm{dpp}$ with a similar trend at $14 \mathrm{dpp}$. No other breed differences were observed.

The proportion of Ki67-positive Sertoli cells increased $(P<0.001)$ from $75 \mathrm{dpc}$, was maximal around $90 \mathrm{dpc}$ (Fig. $4 \mathrm{~B})$ and declined thereafter in both breeds $(P<0 \cdot 01)$. Breed differences were not observed from $60 \mathrm{dpc}$ through $7 \mathrm{dpp}$, but WC boars had a greater proportion of proliferating (Ki67-positive) Sertoli cells at 14 and $25 \mathrm{dpp}$ compared with MS boars (Fig. 4B).

At $60 \mathrm{dpc}$, plasma FSH concentrations were undetected in $37 \%$ of the fetuses; if these were assigned the limits of detection, $0.2 \mathrm{ng} / \mathrm{ml}$, then mean concentrations were 1.2 and $1.3 \mathrm{ng} / \mathrm{ml}$ in WC and MS male fetuses. At $75 \mathrm{dpc}$, plasma FSH concentrations were greater $(P<0.05)$ in WC than in MS boars (Fig. 5). FSH concentrations decreased through $105 \mathrm{dpc}$ in WC but increased during this period in MS boars $(P<0 \cdot 01$, Fig. 5). From $105 \mathrm{dpc}$ to $1 \mathrm{dpp}$, FSH increased in WC but decreased in MS boars (Fig. 5). From 1 to 25 dpp, plasma FSH concentrations decreased in boars of both breeds $(P<0 \cdot 001)$.

Total numbers of germ cells increased with advancing age during fetal and neonatal life $(P<0 \cdot 001)$. Germ cell numbers did not differ between breeds during fetal development, WC boars had greater germ cell numbers than MS boars at $1 \mathrm{dpp}$, but MS boars had substantially more germ cells at 14 and $25 \mathrm{dpp}$ compared with WC boars (Table 1). Breed differences in germ cell nuclear volume were not observed during fetal life, but WC boars 


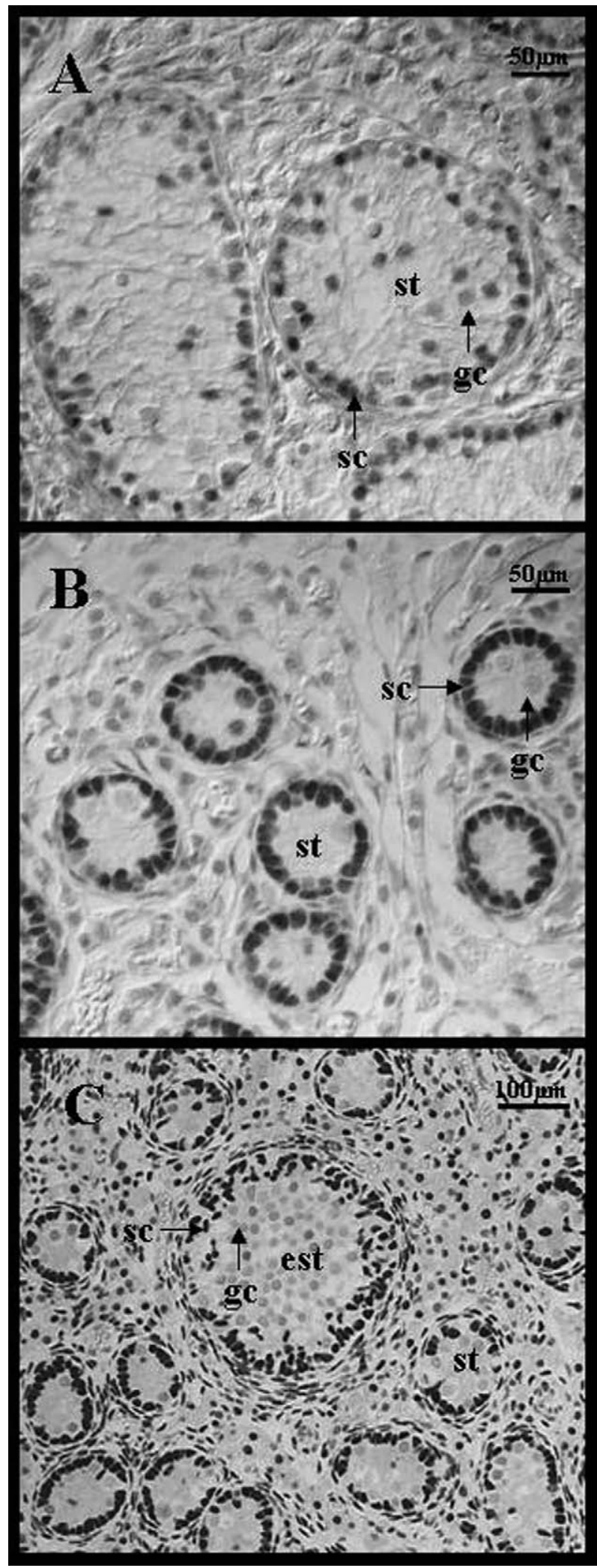

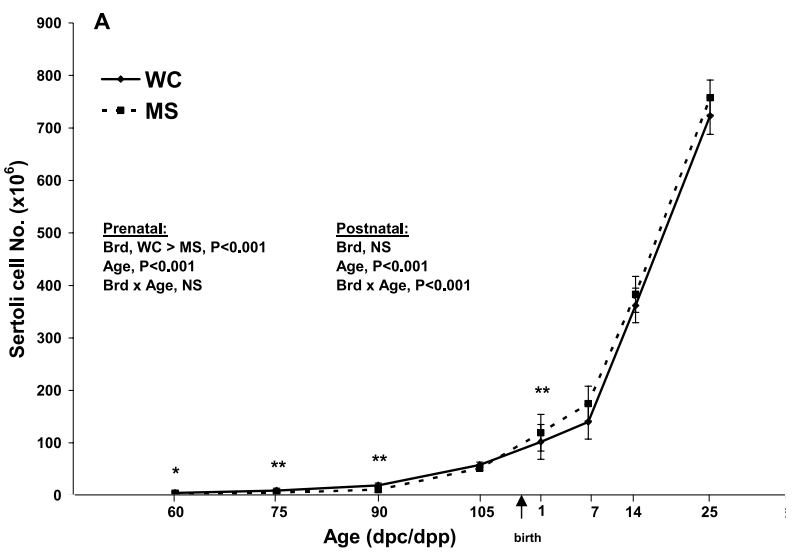

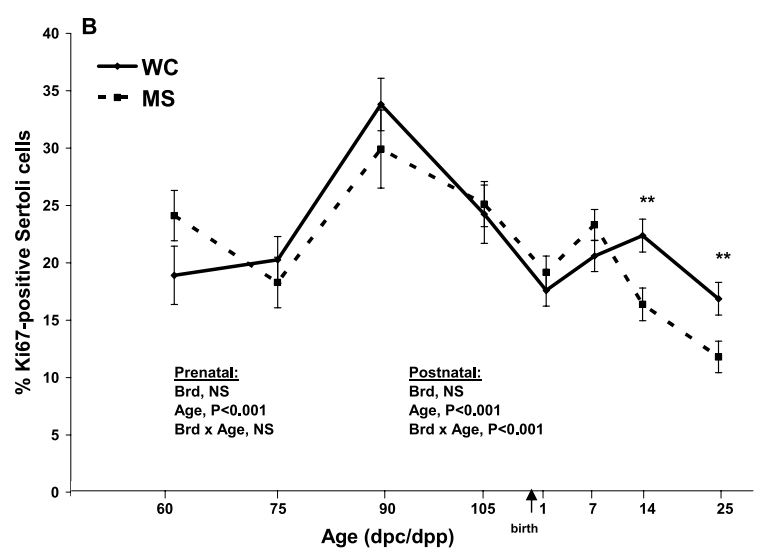

Figure 4 (A) Total Sertoli cell number per testis and (B)

percentage of proliferating (Ki67-positive) Sertoli cells in Meishan (MS) and White Composite (WC) boars during fetal and neonatal life. Data are LSMs \pm S.E. ${ }^{*} P<0 \cdot 05 ;{ }^{*} P<0 \cdot 01 ;{ }^{* *} P<0 \cdot 001 ; \mathrm{dpc}$, days postcoitum; dpp, days postpartum; Brd, Breed; NS, not significant.

had larger germ cell nuclei at 7, 14 and $25 \mathrm{dpp}$ (Table 1). The germ cell to Sertoli cell ratio was greater in MS than WC fetal boars, but breed differences were not observed at postnatal ages (Table 1).

\section{Discussion}

Sertoli cell number is the primary determinant of mature testicular size and capacity to produce sperm (Orth et al. 1988, Russell et al. 1990, Chubb 1992), and thus therein resides potential to decrease production (artificial

Figure 3 Brightfield photomicrographs of (A) Meishan and (B) White Composite boar testes at 25 days postpartum, and (C) Meishan testis at 105 days postcoitum immunohistochemically stained with GATA4. In (C), note the enlarged seminiferous tubules (est) containing many Sertoli cells (sc) and germ cells (gc) as compared with normal seminiferous tubules (st). 


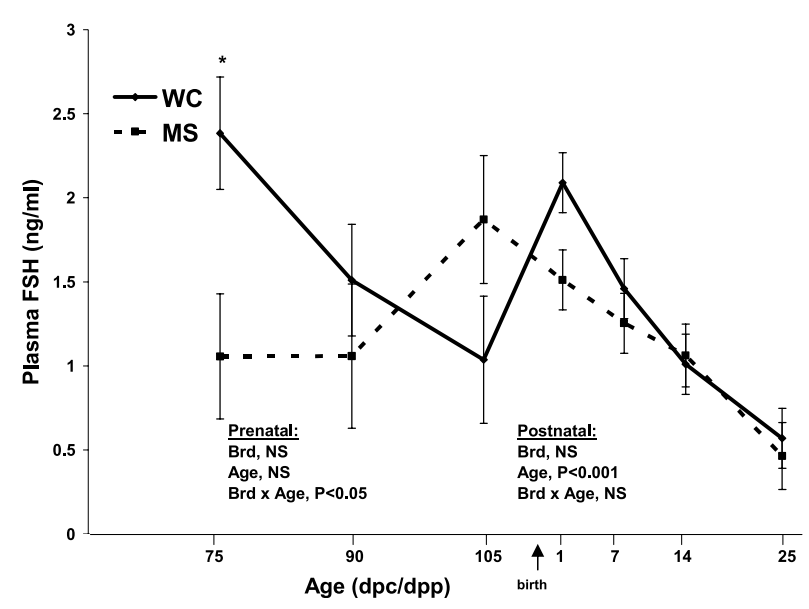

Figure 5 FSH concentrations. Data are LSMs \pm S.E. ${ }^{*} P<0 \cdot 05$; dpc, days postcoitum; dpp, days postpartum; Brd, breed; NS, not significant.

insemination) costs by producing boars with large testes and sperm cells containing superior genes. Potential modification of testicular size is thus dependent on identification of factors that control Sertoli cell population size. This is the first study to describe Sertoli cell population ontogeny in boar testes during fetal and neonatal life using direct stereological methods.

Mature MS boars have smaller testes resulting from fewer Sertoli cells, a greater percentage of interstitial structures but a lower percentage of seminiferous tubules and reduced total daily sperm production compared with European breeds (Okwun et al. 1996, Lunstra et al. 1997). Reduced testicular size in MS boars was evident in this study by $60 \mathrm{dpc}$ and remained lower through $25 \mathrm{dpp}$ compared with WC boars. The mass of seminiferous tubules and interstitial structures both increased with advancing age in each breed during fetal and neonatal life; however, interstitial mass increased at a faster rate in WC than MS testes, accounting for differential testicular size. These breeds were reversed in the rate of seminiferous tubule growth during fetal and early neonatal life, whilst MS boars had a greater mass of tubules by $25 \mathrm{dpp}$ compared with WC boars.

Sertoli cell number during fetal and early neonatal life showed a pattern of development similar to that of tubular mass, as predicted by the strong correlation between tubular mass and Sertoli cell number in prepubertal and mature boars (Russell et al. 1990, Lunstra et al. 1997, Franca et al. 2000). From 60 to $90 \mathrm{dpc}$, tubular mass and number of Sertoli cells were greater in WC than in MS boars and increased synchronously in both breeds. However, after $105 \mathrm{dpc}$ and during early postnatal life, this synchrony was lost. Notably, MS boars had a significantly greater mass of tubules with greater diameter compared with WC boars at $25 \mathrm{dpp}$ despite similar numbers of Sertoli cells.
These observations on numbers of Sertoli cells contrast with those of our earlier study (McCoard et al. 2001a) that identified greater numbers of Sertoli cells in WC than MS boars at $14 \mathrm{dpp}$. Differences in birth weight of the boars in these two experiments potentially account for this inconsistency. In the earlier study, WC boars were disproportionately heavier relative to newborn boars of this genetic line, and their birth weights were $17 \%$ heavier than WC boars of the current study. Whereas, MS boars had similar birth weight in these two studies, $1.05 \mathrm{vs} 1.00 \mathrm{~kg}$. These observations emphasize the significant influence of birth weight on testicular size and Sertoli cell population size in boars and support findings of a related study with MS $\times$ WC crossbred boars that identified a significant influence of birth weight on mature testicular size (J J Ford, unpublished observations). Thus, the current observations should better reflect differences between boars of these two breeds than that which was observed in our earlier study.

An enigma in the current findings is that the greater number of Ki67-positive Sertoli cells in WC boars on 14 and $25 \mathrm{dpc}$ did not translate into a greater total number of Sertoli cells relative to MS boars. The presence of Ki67 identifies cells in all phases of the cell cycle except $G_{0}$ and early $G_{1}$; thus, Sertoli cells of MS boars from 14 to $25 \mathrm{dpp}$ may have a shorter cell cycle with reduced duration of the proliferative phases. Alternatively, cell cycle length and thus proliferation rate of Sertoli cells increased in WC boars during this stage of development, or there may be differences within each breed of boars in Sertoli cell longevity.

Sertoli cell proliferation peaks during late fetal life, declines during postnatal life with the adult complement reached prior to puberty in rats (Means et al. 1976, Orth 1982, Gondos \& Berndtson 1993), mice (Kluin et al. 1984), sheep (Monet-Kuntz et al. 1984) and New World monkeys (Rey et al. 1993). Maximal Sertoli cell proliferation during late fetal life observed in this study illustrates that porcine Sertoli cell population growth is consistent with that in other species, contrasting with earlier reports in pigs employing indirect measures of Sertoli cell population growth (Tran et al. 1981, Putra \& Blackshaw 1985, Kosco et al. 1987, Swanlund et al. 1995). However, in Old World monkeys (Marshall \& Plant 1996) and a strain of wild pigs (Franca et al. 2000) Sertoli cell proliferation continued through pubertal development.

Gonadotropins have been implicated in the regulation of Sertoli cell proliferation in rodents (Orth 1984, Meachem et al. 1996, Baker \& O'Shaughnessy 2001) and monkeys (Marshall \& Plant 1996). In contrast to observations of the current study relative to FSH, Goxe et al. (1993) reported no difference in serum FSH concentration and FSH receptor levels between MS and a White breed of pigs. However, these investigators also observed no difference in gonadal weights between the two breeds. In the present study, maximal proportions of Ki67-positive 
Sertoli cells $(\sim 90 \mathrm{dpc})$ occur prior to the period of maximal FSH concentrations in both breeds. Further, during the first $25 \mathrm{dpp}$, Sertoli cell numbers increase at a more rapid rate in MS than in WC boars, but during this period plasma FSH secretion subsides (Fig. 5; Lunstra et al. 1997, Franca et al. 2000, Ford et al. 2001). This further supports the observation that Sertoli cell proliferation in boars is not accelerated by greater FSH secretion (Ford et al. 2001), in contrast to earlier claims that exogenous FSH had a stimulatory effect (Swanland et al. 1995); however, this study reported on length of seminiferous tubules rather than enumeration of numbers of Sertoli cells. Furthermore, in WC boars, proliferation of Sertoli cells continues until $100 \mathrm{dpp}$ (Tran et al. 1981), a period of reduced FSH secretion, and the magnitude of the neonatal increase in FSH secretion is not related to adult testicular size in boars (Ford et al. 2001). Also, the increase in FSH secretion that occurs after unilateral castration has minimal effect on Sertoli cell proliferation (Lunstra et al. 2003).

Sertoli cells do not proliferate after formation of the blood-testis barrier (Gondos \& Berndtson 1993). The appearance of a lumen within seminiferous tubules coincides with formation of tight junctional complexes and the blood-testis barrier (rat: Tindall et al. 1975, Setchell et al. 1988, Russell et al. 1989, rabbit: Sun \& Gondos 1986, bull: Curtis \& Amann 1981) signifying Sertoli cell maturation. In the present study, decline in Sertoli cell proliferative activity from 14 to $25 \mathrm{dpp}$ coupled with increased seminiferous tubule diameter and Sertoli cell nuclear size, indicators of maturation (Steinberger 1976), signals earlier termination of mitosis and advanced Sertoli cell maturation in MS compared with WC boars. Whilst total Sertoli cell numbers at $25 \mathrm{dpp}$ are the reciprocal of mature Sertoli cell numbers, early termination of mitosis in MS boars would result in a smaller adult Sertoli cell population and smaller testes compared with WC boars. These observations are consistent with the appearance of lumina by $28 \mathrm{dpp}$ and early onset of spermatogenesis (56 dpp) in MS boars (Lunstra et al. 1997), contrasting initiation of lumen formation by $94 \mathrm{dpp}$ (Kosco et al. 1989), and completion by $120 \mathrm{dpp}$ (Tran et al. 1981) in WC boars. These observations further illustrate the considerable breed differences in timing of Sertoli cell maturation and blood-testis barrier formation, and thus duration of the Sertoli cell proliferation period. Compensatory hypertrophy of testes in boars is not accompanied by a large increase in Sertoli cell numbers, irrespective of time of hemicastration (Lunstra et al. 2003), unlike young rams and male rats (Waites et al. 1983, Hochereau-de Reviers et al. 1984, Orth et al. 1984), suggesting mature Sertoli cell population size is genetically determined or preprogrammed prior to birth in boars. Morphological signs of early Sertoli cell maturation by $14 \mathrm{dpp}$ in MS boars in the present study are consistent with this notion.

FSH has been associated with Sertoli cell maturation (Steinberger et al. 1964, Griswold 1993). However, the role for gonadotropins in blood-testis barrier formation is controversial. Absence of germ cells, hypophysectomy and estrogen treatment produce a slight delay but do not prevent or reverse blood-testis barrier formation (Johnson 1973, Vitale et al. 1973, Hagenas et al. 1978), indicating an uncoupling of tight junction formation from gonadotropins. However, tight junctions that lead to the formation of the blood-testis barrier do not form in hypogonadotropic hypogonadic men, but form following gonadotropin treatment (de Krestser \& Burger 1992). Gonadotropindependency of tight junction formation is also supported by others (Tung et al. 1975, Bressler 1976, Janecki et al. 1991a,b), but treatment of rats during postnatal life (0-32 days of age) with antisera to luteinizing hormone or FSH fails to modify Sertoli cell junctional complexes (Chemes et al. 1979). Thus, it is likely that species differences exist in the dependency of blood-testis barrier formation on gonadotropins. Early morphological signs of Sertoli cell maturation observed for MS boars in the present study were not coupled to changes in FSH secretion. Further, blood-testis barrier formation in MS boars occurs at 28-42 dpp (Lunstra et al. 1997) and WC boars at 94-120 dpp (Tran et al. 1981), preceding the pubertal increase in gonadotropins and testosterone (Lunstra et al. 1997), supporting the phenomenon that mature testicular size of boars is not correlated with pubertal increases in gonadotropins and testosterone (Ford et al. 2001).

In summary, this study reports that maximum Sertoli cell proliferation occurs during late fetal life in the pig and is not tightly coupled to FSH secretion. Rather, the number of Sertoli cells in adult testes is probably determined by length of the proliferative period, potentially regulated by Sertoli cell maturation and/or timing of tight junction formation leading to blood-testis barrier formation. Mechanisms that regulate duration of Sertoli cell proliferation in boars remain to be elucidated, but MS and WC boars differ in these.

\section{Acknowledgements}

The authors thank A Kruger, S Hassler and D Griess for their skillful technical assistance, Meat Animal Research Center (MARC) Swine Personnel and MARC abattoir staff for care and handling of the animals and sample collection, and Dr A F Parlow for porcine FSH RIA reagents. In this paper, names are necessary to report factually on available data; however, the United States Department of Agriculture (USDA) neither guarantees nor warrants the standard of the product, and the use of the name by USDA implies no approval of the product to the exclusion of others that may also be suitable.

\section{References}

Baker PJ \& O'Shaughnessy PJ 2001 Role of gonadotrophins in regulating numbers of Leydig and Sertoli cells during fetal and postnatal development in mice. Reproduction 122 227-234. 
Bressler RS 1976 Dependence of Sertoli cell maturation on the pituitary gland in the mouse. American Journal of Anatomy 147 447-455.

Chubb C 1992 Genes regulating testis size. Biology of Reproduction 47 29-36.

Chemes HE, Dym M \& Raj HG 1979 Hormonal regulation of Sertoli cell differentiation. Biology of Reproduction 21 251-262.

Curtis SK \& Amann RP 1981 Testicular development and establishment of spermatogenesis in Holstein bulls. Journal of Animal Science 53 1645-1657.

FASS 1999 Guide for the Care and Use of Agricultural Animals in Agricultural Research and Teaching, 1st rev. edn. Savoy, IL: Federation of Animal Science Societies.

Fawcett DW 1975 Ultrastructure and function of the Sertoli cell. In Handbook of Physiology: Male Reproductive system, vol 5, pp 21-55. Eds DM Hamilton \& RO Greep. Washington DC: American Physiological Society.

Ford JJ, Wise TH, Lunstra DD \& Rohrer GA 2001 Interrelationships of porcine $\mathrm{X}$ and $\mathrm{Y}$ chromosomes with pituitary gonadotropins and testicular size. Biology of Reproduction 65 906-912.

Franca LR, Silva VA Jr, Chiarini-Garcia H, Garcia SK \& Debeljuk L 2000 Cell proliferation and hormonal changes during postnatal development in the pig. Biology of Reproduction 63 1629-1636.

Gondos B \& Berndtson WE 1993 Postnatal and pubertal development. In The Sertoli Cell, pp 116-153. Eds LD Russell \& MD Griswold. Clearwater, FL: Cache River Press.

Goxe B, Prunier A, Remy JJ \& Salesse R 1993 Ontogeny of gonadal luteinizing hormone and follicle-stimulating hormone receptors in the fetal pig and related changes in gonadotropin and testosterone secretion. Biology of Reproduction 49 609-616.

Griswold MD 1993 Action of FSH on mammalian Sertoli cells. In The Sertoli Cell, pp 788-792. Eds LD Russell \& MD Griswold. Clearwater, FL: Cache River Press.

Hagenas L, Ploen L \& Ekwall H 1978 Blood-testis barrier: evidence for intact inter-Sertoli cell junctions after hypophysectomy in the adult rat. Journal of Endocrinology 76 87-91.

Hochereau-de Reviers MT, Land RB, Perreau C \& Thompson R 1984 Effect of season of birth and hemicastration on the histology of the testis of 6 month-old lambs. Journal of Reproduction and Fertility 70 157-163.

Janecki A, Jakubowiak A \& Steinberger A 1991a Regulation of transepithelial electrical resistance in two-compartment Sertoli cell cultures: in vitro model of the blood-testis barrier. Endocrinology 129 1489-1496.

Janecki A, Jakubowiak A \& Steinberger A $1991 b$ Effects of cyclic AMP and phorbol ester on transepithelial cell resistance of Sertoli cell monolayers in two compartment culture. Molecular and Cellular Endocrinology 82 61-69.

Johnson MH 1973 The role of the pituitary in the development of the blood-testis barrier in mice. Journal of Reproduction and Fertility 32 509-511.

de Krestser DM \& Burger HG 1992 Ultrastructural studies of human hypogonadism before and after gonadotropin treatment. In Gonadotropins, pp 640-656. Eds BB Saxena, CG Beling \& HM Gandy. New York, NY: Wiley.

Kluin PM, Kramer MF \& de Rooij DG 1984 Proliferation of spermatogonia and Sertoli cells in maturing mice. Anatomical Embryology 169 73-78.

Kosco MS, Bolt DJ, Wheaton JE, Loseth KJ \& Crabo BG 1987 Endocrine responses in relation to compensatory testicular growth after neonatal hemicastration in boars. Biology of Reproduction $\mathbf{3 6}$ $1177-1185$.

Kosco MS, Loseth KJ \& Crabo BG 1989 Development of the seminiferous tubules after neonatal hemicastration in the boar. Journal of Reproduction and Fertility 87 1-11.

Liwska J 1975 Development of the adenohypophysis in the embryo of the domestic pig. Folia Morphologica 34 211-217.
Lunstra DD, Ford JJ, Klindt J \& Wise TH 1997 Physiology of the Meishan boar. Journal of Reproduction and Fertility $\mathbf{5 2}$ (Suppl) 181-193.

Lunstra DD, Wise TH \& Ford JJ 2003 Sertoli cell in the boar testis: changes during development and compensatory hypertrophy after hemicastration at different ages. Biology of Reproduction 68 140-149.

Marshall GR \& Plant TM 1996 Puberty occurring either spontaneously or induced precociously in rhesus monkey (Macaca mulatta) is associated with a marked proliferation of Sertoli cells. Biology of Reproduction 54 1192-1199.

McCoard SA, Lunstra DD, Wise TH \& Ford JJ 2001a Specific staining of Sertoli cell nuclei and evaluation of Sertoli cell number and proliferative activity in Meishan and White Composite boars during the neonatal period. Biology of Reproduction 64 689-695.

McCoard SA, Wise TH, Fahrenkrug SC \& Ford JJ $2001 b$ Temporal and spatial localization patterns of GATA4 during porcine gonadogenesis. Biology of Reproduction 65 366-374.

Meachem SJ, McLachlan RI, de Krester DM, Robertson DM \& Wreford NG 1996 Neonatal exposure of rats to recombinant follicle stimulating hormone increases adult Sertoli and spermatogenic cell numbers. Biology of Reproduction 54 36-44.

Means AR, Fakunding JL, Huckins C, Tindall DJ \& Vitale R 1976 Follicle-stimulating hormone, the Sertoli cell, and spermatogenesis. Recent Progress in Hormone Research 32 477-522.

Monet-Kuntz C, Hochereau-de Reviers MT \& Terqui M 1984 Variations in testicular androgen receptors and histology of the lamb testis from birth to puberty. Journal of Reproduction and Fertility $\mathbf{7 0}$ 203-210.

Okwun OE, Igboeli G, Ford JJ, Lunstra DD \& Johnson L 1996 Number and function of Sertoli cells, number and yield of spermatogonia, and daily sperm production in three breeds of boars. Journal of Reproduction and Fertility 107 137-149.

Orth JM 1982 Proliferation of Sertoli cells in fetal and postnatal rats: a quantitative autoradiographic study. Anatomical Record 203 485-492.

Orth JM 1984 The role of follicle-stimulating hormone in controlling Sertoli cell proliferation in the testes of fetal rats. Endocrinology 115 $1248-1255$

Orth JM, Higginbotham CA \& Salisbury RL 1984 Hemicastration causes and testosterone prevents enhanced uptake of $\left[{ }^{3} \mathrm{H}\right]$ thymidine by Sertoli cells in testes of immature rats. Biology of Reproduction $\mathbf{3 0}$ 263-270.

Orth JM, Gunsalus GL \& Lamperti AA 1988 Evidence from Sertoli cell-depleted rats indicates that spermatid number in adults depends on numbers of Sertoli cells produced during perinatal development. Endocrinology 122 787-794.

Pelliniemi LJ 1975 Ultrastructure of the early ovary and testis in pig embryos. American Journal of Anatomy 144 89-111.

Putra DK \& Blackshaw AW 1985 Quantitative studies of compensatory testicular hypertrophy following unilateral castration in the boar. Australian Journal of Biological Science 38 429-434.

Rey RA, Campo SM, Bedecarras P, Nagle CA \& Chemes HE 1993 Is infancy a quiescent period of testicular development? Histological, morphometric and functional study of the seminiferous tubules of the cebus monkey from birth to the end of puberty. Journal of Clinical Endocrinology and Metabolism 76 1325-1331.

Russell LD, Bartke A \& Goh JC 1989 Postnatal development of the Sertoli cell barrier, tubular lumen, and cytoskeleton of Sertoli and myoid cells in the rat, and their relationship to tubular fluid secretion and flow. American Journal of Anatomy 184 179-189.

Russell LD, Ren HP, Sinha Hikim I, Schultze W \& Sinha Hikim AP 1990 A comparative study in twelve mammalian species of volume densities, volumes, and numerical densities of selected testis components, emphasizing those related to the Sertoli cell. American Journal of Anatomy 188 21-30.

SAS 1999 SAS User's Guide: Statistics, edn 8. Cary, NC: SAS Institute Inc. 
Setchell BP, Zupp JP \& Pollanen P 1988 Blood-testis barrier at puberty. In Development and Function of the Reproductive Organs, pp 77-79. Eds M Parvinen, I Huhtaniemi I \& LJ Pelliniemi. Rome: Ares-Serono.

Steinberger B, Steinberger A \& Perlof WH 1964 Initiation of spermatogenesis in vitro. Endocrinology 74 788-792.

Steinberger E 1976 Molecular mechanisms concerned with hormonal effects on the seminiferous tubule and endocrine relationships at puberty in the male. In Regulatory Mechanisms of Male Reproductive Physiology, pp 29-34. Eds CH Spilman, TJ Lobl \& KT Kirton. Amsterdam: Excerpta Medica.

Sun EL \& Gondos B 1986 Formation of the blood-testis barrier in the rabbit. Cell and Tissue Research 243 575-578.

Swanlund DJ, N'Diaye MR, Loseth KJ, Pryor JL \& Crabo BG 1995 Diverse testicular responses to exogenous growth hormone and follicle-stimulating hormone in prepubertal boars. Biology of Reproduction 53 749-757.

Tindall DJ, Vitale R \& Means AR 1975 Androgen binding protein as a biochemical marker of formation of the blood-testis barrier. Endocrinology 97 636-648.

Tran D, Muesy-Dessolle N \& Josso N 1981 Waning of anti-Müllerian activity: an early sign of Sertoli cell maturation in the developing pig. Biology of Reproduction 24 923-931.
Tung PS \& Fritz IB 1987 Morphogenetic restructuring and formation of basement membranes by Sertoli cells and testis peritubular cells in coculture: inhibition of the morphogenetic cascade by cyclic AMP derivates and by blocking direct cell contact. Developmental Biology 120 139-153.

Tung PS, Dorrington JH \& Fritz IB 1975 Structural changes induced by follicle-stimulating hormone or dibutryl cyclic AMP on presumptive Sertoli cells in culture. PNAS 72 1838-1842.

Tung PS, Skinner MK \& Fritz IB 1984 Cooperativity between Sertoli cells and peritubular myoid cells in the formation of the basal lamina in the seminiferous tubule. Annals of the New York Academy of Sciences 438 435-446.

Vitale R, Fawcett DW \& Dym M 1973 The normal development of the blood-testis barrier and the effects of clomiphene and estrogen treatment. Anatomical Record 176 333-344.

Waites GM, Wenstrom JC, Crabo BG \& Hamilton DW 1983 Rapid compensatory hypertrophy of the lamb testis after neonatal hemiorchidectomy: endocrine and light microscopical morphometric analysis. Endocrinology 112 2159-2167.

Received 1 May 2003

Accepted 29 May 2003 